Received: 01/11/2018

Revision: 29/04/2019

Accepted: 05/05/2019

OnlineFirst:26/05/2019

\title{
Investigating Critical Thinking Skill of Junior High School in Solving Mathematical Problem
}

\section{Hasan Basri}

Dr. candidate, Postgraduate of Mathematics Education, Universitas Negeri Malang, Lecturer in Universitas Madura, Indonesia, hasan.basri.1603119@students.um.ac.id

\section{Purwanto}

Prof., Postgraduate of Mathematics Education, Universitas Negeri Malang, Indonesia, purwanto.fmipa@um.ac.id

\author{
Abdur Rahman As'ari \\ Dr., Postgraduate of Mathematics Education, Universitas Negeri Malang, Indonesia, \\ abdur.rahman.fmipa@um.ac.id
}

\section{Sisworo}

Dr., Postgraduate of Mathematics Education, Universitas Negeri Malang, Indonesia, sisworo.fmipa.um.ac.id

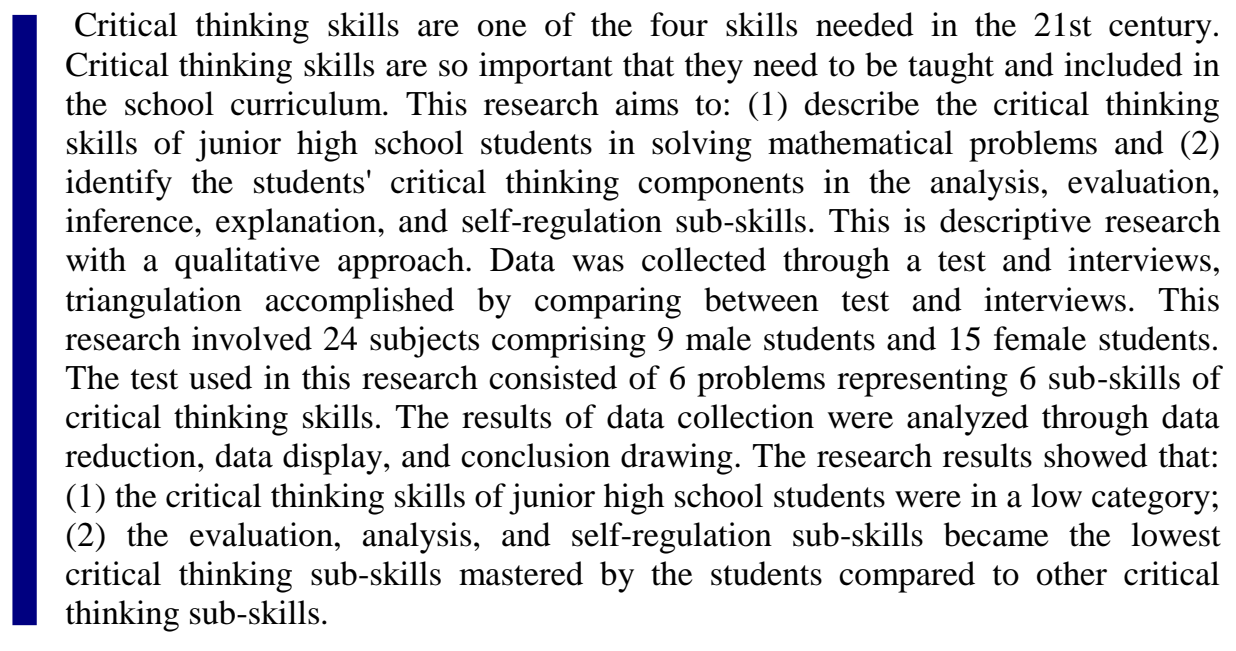

Keywords: investigating, critical thinking, mathematical problem, thinking skill, problem solving

Citation: Basri, H., Purwanto, As'ari, A. R., \& Sisworo. (2019). Investigating Critical Thinking Skill of Junior High School in Solving Mathematical Problem. International Journal of Instruction, 12(3), 745-758. https://doi.org/10.29333/iji.2019.12345a 


\section{INTRODUCTION}

Critical thinking is one of the most essential skills in the 21 st century (Alismail \& Mcguire, 2015; Beers, 2011; Binkley et al., 2010; Brown, 2015; Changwong, 2018; Fadel, 2008; Lamb, 2017). Critical thinking is very important for students because it enables them to solve problems in difficult situations and have effective and accurate communication. Learning to think critically is one of the most desirable goals of the education system (Massa, 2014; Nilson et al., 2014; Radulović \& Stančić, 2017; Tiruneh et al., 2017), causing the term "critical thinking" (CT) is often found in education policy documents. Within the learning context in Indonesia, critical thinking becomes one of the learning objectives, especially in the mathematics course. However, based on the analysis results conducted by the researchers on the National Examination (Ujian Nasional, UN) in Indonesia, the content of the given questions has not been able to measure students' critical thinking skills. One indicator is the multiple-choice questions in the National Examination (Ujian Nasional, UN). This type of question obviously has not been able to see students' thinking process. In addition, many questions in the National Examination (Ujian Nasional, UN) cannot be categorized as problems aimed to measure critical thinking skills. The given questions generally emphasize the application of formulas or theorems and student's memorization ability.

Several experts have conducted studies related to critical thinking skills, including Duran \& Sendag (2012); Kumar \& James (2015); Aktaş \& Ünlü (2013). IT/STEM programs were able to improve students' critical thinking skills. Male students showed more inference and interpretation skills than female students (Kumar \& James, 2015). It is proven that gender has no relationship with assumption and deduction. Critical thinking skills of teacher candidates of elementary mathematics were medium level but not high enough (Aktaş \& Ünlü, 2013). They using the CCTTLX instrument. The instrument contained 4 sub-skills of Induction, Deduction, Observation, and assumption identification. However, the questions were not mathematical questions. According to the researchers, this instrument is less relevant in identifying one's mathematical critical thinking skills. These studies have demonstrated the importance of critical thinking that needs to be studied and reviewed in depth.

Critical thinking skills have become essential competencies for people in the new information age and the global economy society (As'ari, 2014; Mason, 2007; Norman et al., 2017). The rapid growth of information and communication technology has made an increasing amount of available information. People must have critical thinking skills so that they can analyze and compare information as well as construct arguments. Everyone needs to think critically in everyday life (Cottrell, 2005; Atabaki et al., 2015). With critical thinking skills, people will be able to distinguish between correct information and hoaxes, causing them to be not easily fooled by hoaxes. In addition, critical thinking also involves the right logical reasoning and the ability to separate facts from opinions (Chukwuyenum, 2013). Furthermore, critical thinking will encourage students to think deeper and be able to solve problems in school or in the context of everyday life because critical thinking is not only needed in the classroom but also in everyday life (Jacob, 2012). 
Researchers have proposed several definitions of critical thinking. Critical thinking is reasonable reflective thinking focused on deciding what to believe or do (Ennis, 2011). Critical thinking is goal-directed thinking involved in making a decision, interpretation, or solving the problems (Halpern,1998). Critical thinking is defined as skillful, responsible thinking that facilitates good judgment because it relies upon criteria and is sensitive to context (Lipman, 2003). Additionally, critical thinking as the ability to absorb and filter out existing phenomena (Facione, 1990).

Some experts give different opinions about the components in measuring critical thinking skills. Six components of critical thinking skills: Interpretation, Analysis, Evaluation, Inference, Explanation, and Self-Regulation (Facione, 1990). Five dimensions of critical thinking: verbal reasoning, argument analysis, thinking as hypothesis testing, likelihood and uncertainty, and decision making and problem (Halpern, 2012). Ennis describes the components of critical thinking skills as FRISCO which stands for: focus, reason, inference, situation, clarity, and overview (Nilson, 2014). In this research, the researchers developed critical thinking problems based on the sub-skills proposed by Facione because it was considered more suitable for measuring students' critical thinking skills in the mathematics course.

This research aims to (1) describe the critical thinking skills of junior high school students in solving mathematical problems and (2) identify the students' critical thinking components in the analysis, evaluation, inference, explanation, and self-regulation subskills. This initial identification is considered very necessary to find out students' critical thinking skills so that appropriate learning models can be designed based on the research findings. Based on the description of the problem above, the researchers are interested in conducting research entitled "Investigating Critical Thinking of Junior High School in Solving Mathematical Problem".

\section{METHOD}

\section{Design}

This is descriptive research with a qualitative approach. The goal of qualitative descriptive studies is a comprehensive summarization, in everyday terms, of specific events experienced by individuals or groups of individuals (Lambert \& Lambert, 2012). In this research, the researchers describe the critical thinking skills of 24 junior high school students in grade VIII.

\section{Participants}

The study was conducted on junior high school students in grade VIII. The selected school is a school in urban areas with accreditation A. This school is a favorite school because it is able to produce students with a good performance at the local and national level. At Regency-level OSN (National Science Olympiad, Olimpiade Sains Nasional), this school always puts its students to be the Regency's representative at the Provinciallevel OSN. Moreover, the students in this school sometimes receive a gold medal at the National-level OSN. The class used in this study was a Science excellent class. The research subjects were 24 students consisting of 9 male students and 15 female students. 


\section{Instrument}

The instrument used in data collection was a test. The critical thinking skills test consisted of 6 problems to measure interpretation, analysis, evaluation, inference, explanation, and self-regulation sub-skills. In addition to the test, the interviews results were used to validate the data. Data validation in this study used a member check by asking the participants about the response description through interviews (Creswell, 2014). The instruments of the critical thinking test given to the students are presented in table 1 below:

Table 1

The Description of Critical Thinking Test

\begin{tabular}{|c|c|c|c|}
\hline No. & $\begin{array}{l}\text { Critical thinking } \\
\text { sub-skill }\end{array}$ & Indicator & $\begin{array}{l}\text { Amount } \\
\text { of item }\end{array}$ \\
\hline 1 & Interpretation & $\begin{array}{l}\text { Students can understand and express the } \\
\text { meaning of the given mathematical statement }\end{array}$ & 1 \\
\hline 2 & Analysis & Students can analyze the given arguments & 1 \\
\hline 3 & Inference & $\begin{array}{l}\text { Students can provide inferences with logical } \\
\text { reasons }\end{array}$ & 1 \\
\hline 4 & Evaluation & Students can assess the given claim & 1 \\
\hline 5 & Explanation & Students can explain their answer & 1 \\
\hline 6 & Self-Regulation & $\begin{array}{l}\text { Students can find the mistake in solution of the } \\
\text { problem }\end{array}$ & 1 \\
\hline \multicolumn{3}{|c|}{ Total items } & 6 \\
\hline
\end{tabular}

\section{Procedures}

This study involved 24 junior high school students in grade VIII aged between 13-14 years old. All students were given a math test to measure their critical thinking skills. The test should be finished in 50 minutes. Then, the students' answer sheets were given the number of 1-24 to facilitate the coding. Students' answers were assessed based on the rubric made by the researchers. In addition, interviews were conducted gradually with the students for 15-25 minutes.

\section{Data Analysis}

Data analysis was conducted through three stages (1) Data from the test and interview results were reduced by selecting important data and eliminating useless data; (2) data from the test results were analyzed by calculating the percentage. In addition to being presented in the percentages form, several test and interview results were described descriptively and presented in six parts, i.e.: (a) students' critical thinking skills in the interpretation sub-skill, (b) students' critical thinking skills in the analysis sub-skill, (c) students' critical thinking skills in the evaluation sub-skill, (d) students' critical thinking skills in the inference sub-skill, (e) students' critical thinking skills in the explanation sub-skill, and (f) students' critical thinking skills in the self-regulation sub-skill. The criteria of the average score are presented in table 2 below; (3) the conclusion of the results of the deduced findings and data display. 
Table 2

The Criteria of Average Scores

\begin{tabular}{ll}
\hline Average score & Criteria \\
\hline $75 \%<P \leq 100 \%$ & Good \\
$60 \%<P \leq 75 \%$ & Fair \\
$P \leq 60 \%$ & Low \\
\hline
\end{tabular}

Adapted from (Seventika et al., 2018).

\section{FINDINGS}

Based on the analysis results on the test and interview data, students' critical thinking skills for each sub-skill were obtained as follows:

\section{Interpretation}

Based on the analysis results in the interpretation sub-skill, 15 students $(63 \%)$ were able to draw a good interpretation, while 9 students $(27 \%)$ were not able to draw a correct interpretation. Some student work results and interviews results of the students with low interpretation sub-skill are presented below.

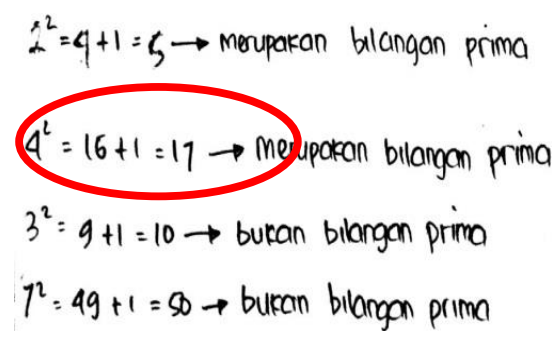

Subject 3 (S3)
$2^{2}=4+1=5 \rightarrow$ It is a prime number

$=16+1=17 \rightarrow$ ID is a prime number

$3^{2}=9+1=10 \rightarrow$ It is not a prime number

$7^{2}=49+1=50 \rightarrow$ It is not a prime number

Translation of Subject 3's (S3) answers

$\mathrm{R}$ : Do you understand the meaning of the given question?

S3 : Yes, Sir.

$\mathrm{R}$ : Can you explain what is being asked in the question?

S3 : Look for two boom numbers and non-boom numbers.

$\mathrm{R}$. You have not provided an answer regarding boom numbers and non-boom numbers (while showing subject 3's work)

S3 : Well, 2 and 4 are boom numbers while 3 and 7 are non-boom numbers.

$\mathrm{R}$ : Why do you categorize the numbers of 2 and 4 as boom numbers while the numbers of 3 and 7 as non-boom numbers?

Yes, Sir. It is because when the numbers of 2 and 4 are squared and added

S3 : one, they become prime numbers, but when the numbers of 3 and 7 are squared and added one, they are not prime numbers.

$\mathrm{R}$ : Have you ever had a question like this or something similar before?

S3 : No, Sir. 
Based on the student work results and interview results, it can be concluded that the failure of subject 3 in drawing a correct interpretation occurred because subject 3 did not fully understand the provided information in the question. Subject 3 only interpreted that boom numbers became prime numbers when they were squared and added one and ignored the information that boom numbers were numbers divisible by 3 . The redcircled part showed that the student did not understand the meaning of "=" correctly. In addition, the obstacle faced by the student was she had never encountered a similar problem before.

\section{Analysis}

Based on the analysis results in the analysis sub-skill, 11 students (46\%) were able to do a good analysis, while 13 students $(54 \%)$ were not able to do an accurate analysis. Some student work results and interview results of the students with low analysis sub-skill are presented below.

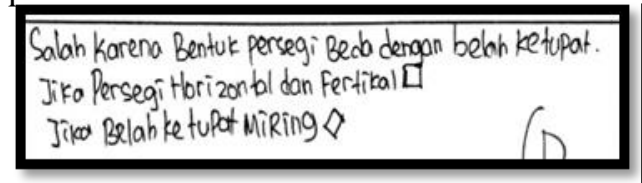

Subject 19 (S19)
It is wrong because the square shape is different from the rhombus shape. A square has vertical and horizontal sides.

A rhombus nas sloping sides.

$\mathrm{R} \quad$ : Is the square always like this (while pointing to the student work results)?

S19 : Yes, Sir.

$\mathrm{R} \quad$ : Is the rhombus always like this (while pointing to the student work results)?

S19 : Yes, Sir.

$\mathrm{R}$ : (Making a square on a piece of paper according to what S19 makes) Is this

$\mathrm{R}:$ a square?

S19 : Yes, Sir.

$\mathrm{R} \quad$ : (rotating the square picture about $45^{\circ}$ ) Is this picture a square?

S19 : (S19 seems doubtful in answering)

$\mathrm{R}$ : How?

S19 : It should be, Sir, because the picture is the same as the one before.

$\mathrm{R}$. Then, why do you analyze the figures only from the picture? Not from the properties.

S19 : So far, I have worked on the square figure with that kind of picture, sir.

Based on student works results and interview results, it can be concluded that subject 19 distinguished the square and rhombus only from the visual pictures without analyzing the properties of those plane figures. Teachers are expected to make various visualizations of plane figures and solid figures to minimize the conceptual errors which might occur to students as experienced by Subject 19 . 


\section{Evaluation}

Based on the analysis results in the evaluation sub-skill, 4 students (17\%) were able to make a good evaluation, while 20 students $(83 \%)$ were not able to make a right evaluation. Some student works results and interviews results of the students with low evaluation sub-skill are presented below.
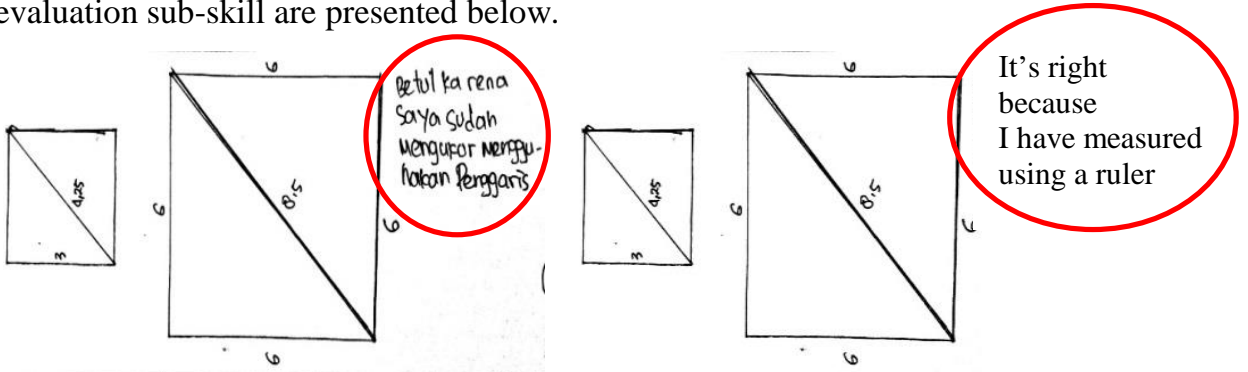

Subject 19 (S19)

Translation of subject 19's (S19) answer

$\mathrm{P}$ : Does the question provide information about the side length of the square?

S19 : (looking back at the question) No, Sir.

$\mathrm{P} \quad$ : Why do you assume that the side length of the square is 3?

S19 : Make it easy for me to answer the question, Sir.

$\mathrm{P} \quad$ : Can you answer without drawing anything?

S19 : (thinking) I'm confused, Sir.

$\mathrm{P} \quad$ : Use the Pythagorean theorem! Do you still remember the Pythagorean theorem?

S19 : I totally forget that, Sir.

Based on student work results and interview results, it can be concluded that S19 could not provide a mathematical proof for the statement. S19 used pictures to prove the statement. In mathematics, pictures act as auxiliary tools and cannot be used as a tool to provide a mathematical proof.

\section{Inference}

Based on the analysis results in the inference sub-skill, 7 students (29\%) were able to draw a good inference, while 17 students $(71 \%)$ were not able to draw a correct inference. Some student work results and interview results of the students with low inference sub-skill are presented below.

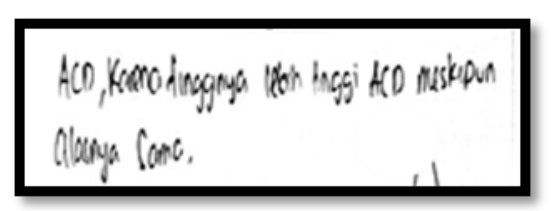

Subject 8 (S8)
ACD because ACD has a higher height albeit the base is the same.

Translation of subject 8's (S8) answer

$\mathrm{R}$ : What is the formula for the area of a triangle? 
S8 : Half of the base times height, Sir.

$\mathrm{R}$ : Can you show me the height of the ACD triangle and the height of the $\mathrm{ABC}$ triangle?

S8 : Yes, Sir (showing the height of the two triangles).

$\mathrm{R}$ : Try to draw the height here (giving a triangle picture).

S8 :

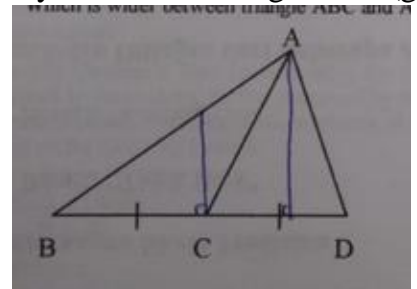

$\mathrm{R} \quad$ : What is the height of the triangle?

S8 : A side that is perpendicular to the base, Sir.

Based on student work results and interview results, it can be concluded that S8 knew the formula for the area of a triangle. However, S8 was not able to identify the height of the triangle correctly. S8 had a misconception related to the height of the triangle.

\section{Explanation}

Based on the analysis results in the explanation sub-skill, 8 students (33\%) were able to make a good explanation, while 16 students $(67 \%)$ were not able to make a right explanation. Some student work results and interview results of the students with low explanation sub-skill are presented below.

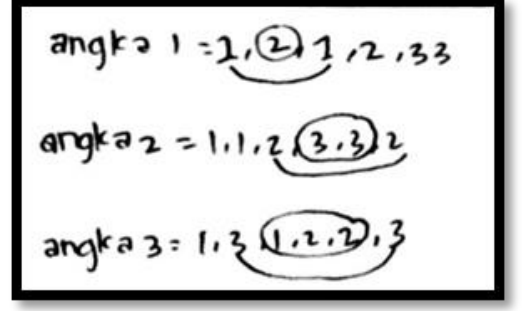

Subject 11's (S11) Answer

$\mathrm{R}$ : What is being asked in the question?

S11 : Determines the smallest number that satisfies the given conditions, Sir.

$\mathrm{R} \quad$ : Can you explain your answer?

S11 : Yes, Sir

$\mathrm{R} \quad$ : Try to explain!

S11 : The number of 1 is separated by one other number, Sir (while pointing to what he wrote the first time on the answer sheet). The number of two is separated by two other numbers like this, Sir.

$\mathrm{R}$ : Okay, I understand what you mean. Does the question ask to be one on one 
like this?

S11 : (Looks doubtful) Well, I guess so, Sir.

Based on the results of the students' work, it can be seen that the student did not answer the questions clearly and seemed doubtful at the end of the interview. It indicated that the student was not able to make a good explanation yet.

\section{Self-Regulation}

Based on the analysis results in the self-regulation sub-skill, 5 students $(21 \%)$ were able to do good self-regulation, while 19 students $(79 \%)$ were not able to do appropriate selfregulation. Some student work results and interview results of the students with low selfregulation sub-skill are presented below.

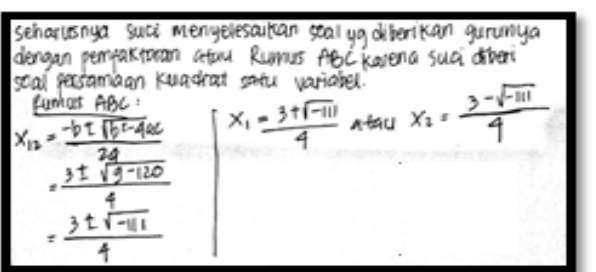

Subject $13(\mathrm{~S} 13)$

R: Why do we

Why do we have to use the ABC formula?

S13: Because it is a quadratic equation, so we have to use the $\mathrm{ABC}$ formula or factorization.

R: $\quad$ So, do you think the method used by Suci is wrong?

S13: Yes, Sir.

Based on the student work results and interview results, it can be concluded that S13 had not understood other procedures that could be used in solving or finding solutions for the quadratic equation.

Table 3

Recapitulation of the Critical Thinking Sub-Skills

\begin{tabular}{llll}
\hline No. & Critical Thinking Sub-Skills & $\begin{array}{l}\text { Percentage of the students with good } \\
\text { critical thinking skills }\end{array}$ & Category \\
\hline 1 & Interpretation & $63 \%$ & Fair \\
2 & Analysis & $46 \%$ & Low \\
3 & Evaluation & $17 \%$ & Low \\
4 & Inference & $29 \%$ & Low \\
5 & Explanation & $33 \%$ & Low \\
6 & Self-regulation & $21 \%$ & Low \\
\hline
\end{tabular}

Based on table 3 above, of the 6 critical thinking sub-skills identified, only the interpretation sub-skill was in the fair category, while the remaining 5 sub-skills of students' critical thinking were in a low category. The evaluation, self-regulation, and 
inference sub-skills were the sub-skills with the lowest percentage. It can be concluded that many students were less capable in those critical thinking sub-skills.

\section{DISCUSSION}

Based on the research results, students' critical thinking skills were in a low category. It can be seen from the students' skills in each of the critical thinking sub-skills were in a low category. The research results are similar to the research conducted by Akgun \& Duruk (2016), As'ari et al (2017), Biber et al (2013) which concluded low critical thinking skills. The difference between the researches was only on the subject under the study. Akgun \& Duruk (2016), As'ari et al (2017), Biber et al (2013) examined critical thinking skills in prospective mathematics teachers. These findings indicated that the critical thinking skills of prospective teachers and students were still in a low category. The research results should enable mathematics teacher educators to design curricula, courses, and/or teaching practices that could improve the critical thinking skills of prospective mathematics teachers, which in the long term could help Indonesian students to have better critical thinking skills.

Interpretation is one of the critical thinking sub-skills (Facione, 1990; Watson \& Glaser, 2002). In this sub skill based on the results of data analysis, information is obtained that students fail because they do not understand the concept well and do not understand the information about the questions in their entirety. This finding is in line with the findings of Phonapichat et al. (2014) that students have difficulty understanding the keywords contained in the question, so students are not able to interpret the problem in mathematical form. Based on the results of interviews, it was known that this happened because the students had just obtained the question for the first time, this is in line with the findings of Jimenez (2010) who stated that students were not able to interpret well because the problems faced were unfamiliar.

Analysis is one of the critical thinking sub-skills (Facione, 1990; Halpern, 2012). In the Revised Bloom's Taxonomy, evaluation is the fourth level of the six cognitive process dimensions (Anderson., 2001). Analysis is a relation to assumptions, classify and distinguishes (Omar, 2012). Based on the data analysis obtained, students have not been able to distinguish, identify and categorize rhombus and square properly. This indicates that students' sub-skill analysis is still lacking. This finding is in line with the results of the Seventika et al. (2018) \& Hidayanti (2016) studies which found that students' sub skills analysis was in the low category

Evaluation is one of the critical thinking sub-skills (Facione, 1990; Watson \& Glaser, 2002). In the Revised Bloom's Taxonomy, evaluation is the fifth level of the six cognitive process dimensions (Anderson., 2001). Evaluation shall mean discriminate the value using definite criteria and make comparisons (Omar, 2012). Based on data analysis, students could not provide mathematical proof to verify that when the side length of the square is extended twice, the diagonals will be doubled from the previous. It indicates that the students lacked evaluation sub-skill.

Inference is one of the critical thinking sub-skills (Ennis, 2011; Facione, 1990; Watson \& Glaser, 2002). Halpern (2012) does not directly state that inference is one of the 
components in measuring critical thinking skills. However, he uses the term of decision making which means the same as inference. Inference means to identify and secure elements needed to draw a reasonable conclusion (Facione, 2011). Based on data analysis, the student gave incorrect inference regarding the comparison of two triangles. The student failed to give correct inference because s/he could not identify the height of the obtuse triangle. These findings are in line with the research results from Seventika et al. (2018) and Hidayanti (2016) which found that the students' sub-skills were in a low category.

Explanation is one of the sub skills of critical thinking skills (Facione, 1990). The experts define the explanation as being able to present in a cognitive and consistent way the results of one 's reasoning (Facione, 2011). Based on the results of the analysis there are many students who cannot answer correctly, this can be seen from the results of student work. From the results of interviews, some students said they were unsure of the answers they had made. This indicates that students are still weak in doing "explanation". Some indicators that cause students' failure in making a good explanation are students' knowledge regarding mathematical concepts that are still low, this result is in line with the research conducted by Hamel et al. (2015) who found that increasing sub-skill explanation along with increasing student knowledge.

Self-regulation is one of the critical thinking sub-skills (Facione, 1990). Based on data analysis in the problem used to measure self-regulation, many students were not able to make corrections to the mistake in the questions. One of the causes of low selfregulation was the students had no skepticism. Skeptical attitudes can encourage a person to reflect so as to produce a correct conclusion and make the right decision (Nugroho, 2018). A study related to self-regulation has been conducted by (Bozpolat, 2016) who found that gender and academic achievement influence self-regulation. A learning model is expected to be developed to improve the students' self-regulation subskill.

\section{CONCLUSION}

Based on the results of data analysis and discussion, it can be concluded that students' critical thinking skills were still in the low category. From the analysis of the six critical thinking sub-skills (interpretation, analysis, evaluation, inference, explanation, and selfregulation), the interpretation sub-skill was in a fair category because more than $60 \%$ of students were able to draw a good interpretation. In addition, the evaluation, analysis, and self-regulation sub-skills became the lowest critical thinking sub-skills mastered by the students compared to other critical thinking sub-skills.

Based on the research results, several recommendations to improve mathematical critical thinking skills include applying a learning method or model which can improve students' critical thinking skills especially in the evaluation, analysis and self-regulation sub-skills and developing an instrument to measure students' critical thinking skills because so far the measurement of mathematical thinking skills using content that does notninvolve specific subject matter expertise such as CCTST, WGCTA, and HCTA. 


\section{REFERENCES}

Akgun, A., \& Duruk, U. (2016). The investigation of preservice science teachers' critical thinking dispositions in the context of personal and social factors. Science Education International, 27(1), 3-15.

Aktaş, G. S., \& Ünlü, M. (2013). Critical Thinking skills of teacher candidates of elementary mathematics. Procedia - Social and Behavioral Sciences, 93, 831-835.

Alismail, H. A., \& Mcguire, P. (2015). 21 st century standards and curriculum : current research and practice. Journal of Education and Practice, 6(6), 150-155.

Anderson, L. W., Krathwohl, D. R., Airasian, P. W., Cruikshank, K. A., Mayer, R. E., Pintrich, P. R., Raths, J., \& Wittrock, M. C. (2001). A Taxonomy for learning, teaching, and assissing: A Revision of bloom's taxonomy of educational objectives. New York: Longman.

As'ari, A. R. (2014). Ideas for developing critical thinking at primary school level. Paper presented at the International Seminar on Addressing Higher Order Thinking: Critical Thinking Issues in Primary Education, At Universitas Islam Muhammadiyah Makasar Sulawesi Selatan.

As'ari, A. R., Mahmudi, A., \& Nuerlaelah, E. (2017). Our Prospective mathematic teachers are not critical thinkers yet. Journal on Mathematics Education, 8(2), 145-156.

Bayu Nugroho, P., Nusantara, T., As'ari, A. R., \& Hidayanto, E. (2018). Critical thinking disposition: Students Skeptic in dealing with ill-logical mathematics problem. International Journal of Instruction, 11(3), 635-648.

Beers, S. Z. (2011). 21 st century skills : Preparing students for THEIR future. STEM. Retrieved from http://cosee.umaine.edu/files/coseeos/21st_century_skills.pdf.

Biber, A. C., Tuna, A., \& Incikabi, L. (2013). An investigation of critical thinking dispositions of mathematics teacher candidates. Educational Research, 4(2), 21415161.

Binkley, M., Erstad, O., Herman, J., Raizen, S., Ripley, M., \& Ripley, M. (2010). Draft white paper 1 defining 21 st century skills. The University of Melbourn. Retrieved from http://cms.education.gov.il/NR/rdonlyres/19B97225-84B1-4259-B423-

4698E1E8171A/115804/defining21stcenturyskills.pdf

Bozpolat, E. (2016). Investigation of the self-regulated learning strategies of students from the faculty of education using ordinal logistic regression analysis. Kuram ve Uygulamada Egitim Bilimleri, 16(1), 301-318.

Brown, B. (2015). Twenty first century skills: A bermuda college perspective, Voices in Education, 1, 58-64.

Changwong, K. (2018). Critical thinking skill development: Analysis of a new learning management model for Thai high schools. Journal of International Studies 11(2), 37- 
48. doi: 10.14254/2071-8330.2018/11-2/3.

Chukwuyenum, A. N. (2013). Impact of critical thinking on performance in mathematics among senior secondary school students in lagos state. Journal of Research \& Method in Education, 3.5(5), 18-25.

Cottrell. (2005). Critical thinking skills: Developing effective analysis and argument. New York N. Y: Palgrave Macmillan.

Creswell, J. W. (2014). Research design. Los Angeles: SAGE.

Duran, M., \& Sendag, S. (2012). A preliminary investigation into critical thinking skills of urban high school students: Role of an IT / STEM program. Creative Education, $3(2), 241-250$.

Ennis, R. H. (2011). The nature of critical thinking: An outline of critical thinking dispositions. University of Illinois.

Facione, P. A. (1990). Critical thinking: A statement of expert consensus for purposes of educational assessment and instruction executive summary (The Complete American Philosophical Association Delphi Research Report). California: The California Academic Press.

Facione, P. A. (2011). Critical thinking: What it is and why it counts. Milbrae: California Academic Press

Fadel, C., Lead, G., \& Systems, C. (2008). Century skills: How can you prepare students for the new Global Economy? Paris.

Halpern, D. F. (1998). Teaching critical thinking for transfer across domains. American Psychologist, 53(4), 449-455.

Halpern, D. F. (2012). Halpern critical thinking assessment: Test manual. Austria: Schuhfried GmbH.

Hamel, C., Turcotte, S., Laferrière, T., \& Bisson, N. (2015). Improving students' understanding and explanation skills through the use of a knowledge building forum. McGill Journal of Education, 50(1), 1-81.

Hidayanti, D. (2016). Analisis kemampuan berpikir kritis siswa smp kelas ix pada materi kesebangunan. Konferensi Nasional Penelitian Matematika Dan Pembelajaran, 2502-6526 (Knpmp I), 276-285.

Jacob, S. M. (2012). Mathematical achievement and critical thinking skills in asynchronous discussion forums. Procedia - Social and Behavioral Sciences, 31(2011), 800-804.

Lamb, S. (2017). Key skills for the 21st century: An evidence-based review. Melbourne Australia: State of New South Wales.

Lambert, V., \& Lambert, C. (2012). Editorial: Qualitative descriptive research: An acceptable design. Pacific Rim International Journal of Nursing Research, 16(4), 255- 
256.

Lipman, M. (2003). Thinking in education second edition. Australia: Cambridge University Press.

Mason. (2007). Critical thinking and learning. Educational Philosophy and Theory, 339-349.

Massa, S. (2014). The development of critical thinking in primary school: The role of teachers ' beliefs. Procedia - Social and Behavioral Sciences, 141, 387-392.

Mohammad, A., Atabaki, S., Keshtiaray, N., \& Yarmohammadian, M. H. (2015). Scrutiny of Critical Thinking Concept. International Education Studies, 8(3), 93-102. doi:10.5539/ies.v8n3p93.

Nilson. (2014). Developing children's critical thinking through creative arts exposure: An application of ennis's super-streamlined critical thinking framework. The International Journal of Arts Education, 8, 31-45.

Norman, M., Chang, P., \& Prieto, L. (2017). Stimulating critical thinking in U.S business students through the inclusion of international students. Journal of Business Diversity, 17(1), 122-130.

Omar, N., Sufi, S., Hassan, R., \& Arshad, H. (2012). Automated analysis of exam questions according to bloom's taxonomy. Procedia - Social and Behavioral Sciences, 59, 297-303.

Phonapichat, P., Wongwanich, S., \& Sujiva, S. (2014). An analysis of elementary school students' difficulties in mathematical problem solving. Procedia - Social and Behavioral Sciences, 116, 3169-3174.

Jimenez, P. K. (2010). Students' interpretations of mathematical statements involving quantification. Mathematics Education Research Journal, 22(3), 41-56.

Kumar, R. R., \& James, R. (2015). Evaluation of critical thinking in higher education in Oman. International Journal of Higher Education, 4(3), 33-43.

Radulović, L. \& Stančić, M. (2017). What is Needed to Develop Critical Thinking in Schools? C-E-P-S Journal, 7(3), 9-25.

Seventika, S. Y., Sukestiyarno, Y. L., \& Mariani, S. (2018). Critical thinking analysis based on Facione (2015) - Angelo (1995) logical mathematics material of vocational high school (VHS). Journal of Physics: Conference Series, 983(1), 012067.

Tiruneh, D. T., De Cock, M., Weldeslassie, A. G., Elen, J., \& Janssen, R. (2017). Measuring critical thinking in physics: Development and validation of a critical thinking test in electricity and magnetism. International Journal of Science and Mathematics Education, 15(4), 663-682.

Watson, G., \& Glaser, E. (2002). Watson-Glaser critical thinking appraisal-UK edition practice test. Londan: Pearson. 